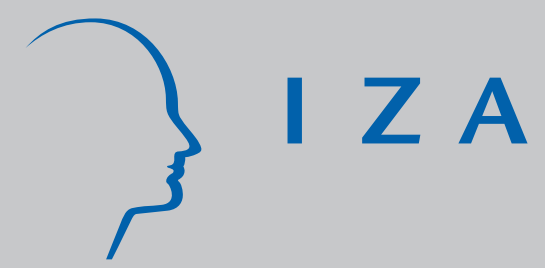

IZA DP No. 6264

Do Europe's Minimum Income Schemes Provide Adequate Shelter against the Economic Crisis and How, If at All, Have Governments Responded?

Sarah Marchal

Ive Marx

Natascha Van Mechelen

December 2011 


\title{
Do Europe's Minimum Income Schemes Provide Adequate Shelter against the Economic Crisis and How, If at All, Have Governments Responded?
}

\author{
Sarah Marchal
}

University of Antwerp

\author{
Ive Marx \\ University of Antwerp \\ and IZA
}

Natascha Van Mechelen

University of Antwerp

Discussion Paper No. 6264
December 2011

IZA

P.O. Box 7240

53072 Bonn

Germany

Phone: +49-228-3894-0

Fax: +49-228-3894-180

E-mail: iza@iza.org

Any opinions expressed here are those of the author(s) and not those of IZA. Research published in this series may include views on policy, but the institute itself takes no institutional policy positions.

The Institute for the Study of Labor (IZA) in Bonn is a local and virtual international research center and a place of communication between science, politics and business. IZA is an independent nonprofit organization supported by Deutsche Post Foundation. The center is associated with the University of Bonn and offers a stimulating research environment through its international network, workshops and conferences, data service, project support, research visits and doctoral program. IZA engages in (i) original and internationally competitive research in all fields of labor economics, (ii) development of policy concepts, and (iii) dissemination of research results and concepts to the interested public.

IZA Discussion Papers often represent preliminary work and are circulated to encourage discussion. Citation of such a paper should account for its provisional character. A revised version may be available directly from the author. 


\section{ABSTRACT}

\section{Do Europe's Minimum Income Schemes Provide Adequate Shelter against the Economic Crisis and How, If at All, Have Governments Responded?}

The present economic crisis comes against the background of decades of policy changes that have generally weakened the capacity of social safety nets to offer citizens with adequate resources for financial survival when labour markets fail to do so. Building on data for 24 European Union countries, this paper asks whether EU governments implemented additional measures during the first phase of the crisis to improve safety nets. Our data, drawn from a large network of national experts, show that many countries introduced supportive measures, in particular in the form of additional increases in gross minimum income benefits. More generous child benefits have also helped to increase net disposable incomes of families on minimum income. Behavioral requirements imposed on minimum income recipients have been neither tightened nor relaxed. In a limited number of countries, activation efforts aimed at minimum income recipients have been intensified. Despite some improvements, social safety nets in Europe remain far below widely accepted poverty thresholds, including the EU's own official measure.

JEL Classification: $\quad$ I38, H75, H12

Keywords: minimum incomes, poverty, crisis measures, social policy, Europe

Corresponding author:

Ive Marx

Herman Deleeck Centre for Social Policy

University of Antwerp

Sint-Jacobstraat 2

2000 Antwerp

Belgium

E-mail: ive.marx@ua.ac.be 


\section{Introduction}

The financial and economic crisis we are witnessing today presents the ultimate challenge to Europe's welfare states and particularly to the social safety nets there present. There has long been an interest in the role such major shocks play in shaping and re-shaping policies, possibly pulling long-standing (path-dependent or even path-trapped) policy trajectories off course (Castles, 2010; Chung \& Thewissen, 2011; Vis, van Kersbergen, \& Hylands, 2011). In that sense the crisis is of major scholarly interest.

Arguably even more important is a more basic question. Do minimum income protection systems as these exist in the EU today succeed in protecting citizens against calamities over which they have little control and for which they cannot be held responsible? We know from earlier studies that the crisis comes against the background of decades of policy changes that have generally (but not universally) weakened the capacity of European welfare states to provide citizens with adequate incomes when labour markets fail to do so (Cantillon, Van Mechelen, Marx, \& Van den Bosch, 2004; Nelson, 2010, forthcoming; Pfeifer, Bahle, \& Hubl, 2011; Van Mechelen \& Marchal, forthcoming). But exactly how adequate are minimum income provisions today and where are improvements most urgently needed?

The focus of this paper is on the initial response to the economic crisis, in the period 2008-mid 2010. This paper deals with two questions, building on data gathered through a network of national experts. First, how, if at all, did EU governments adjust their minimum income protection policies in response to the crisis? Did that response prove to be a path-breaking or path-reinforcing event? And was there any communality in the response across the EU? Second, do minimum income schemes in the EU provide adequate protection against poverty?

In the following section we present our data. Section three briefly touches upon changes in minimum income caseloads since the onset of the crisis. In section four we look at trends in gross benefit levels and at changes in other income components affecting net income packages of minimum income recipients. We also assess the net income packages of minimum income recipients relative to the EU at-risk-of-poverty threshold. Section five extends this analysis and looks at aspects of conditionality. Section six concludes.

\section{Data}

The analysis draws on data gathered in the CSB-MIPI dataset. CSB-MIPI contains information on minimum income protection provisions for workers, for people at working age not in work, and for the elderly. By first defining the group at risk (for this paper, the working-aged able-bodied who fall outside the social insurance scheme and are without a job), equivalent schemes are compared across countries, instead of schemes that merely have a similar name. Table 1 provides an overview of the schemes selected based on this risk-type approach. 
Table 1. Overview of European social assistance schemes for able-bodied persons of working age, 2009

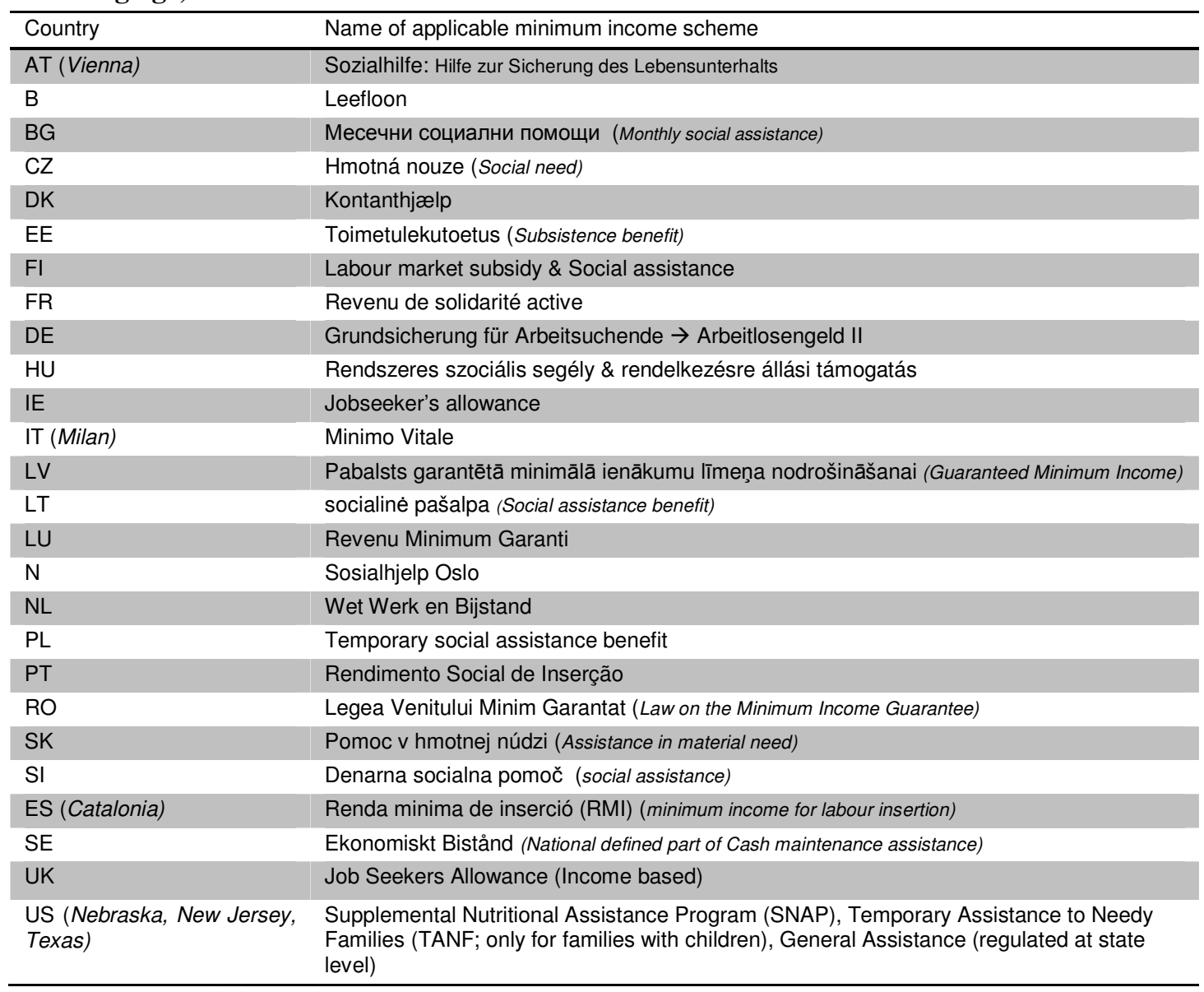

Source: Van Mechelen et al. (2011: 9-10)

The data is provided by national experts on the basis of detailed questionnaires and instructions. Many have participated in earlier studies on social benefit packages (Bradshaw \& Finch, 2002; Eardley, Bradshaw, Ditch, Gough, \& Whiteford, 1996) and/or currently participate in EUROMOD ${ }^{1}$. They are listed in appendix.

The CSB-MIPI dataset contains gross time series on minimum wages, minimum income benefits and minimum income guarantees for elderly spanning two decades, from 1992 until 2009. The main focus of the dataset is on model family simulations of net disposable income for five household types per income situation, taking full account of taxes, social security contributions, means-tested supplements and child benefits. These simulations refer to three points in time, i.e. May 1992, June 2001 and June 2009.

During the last round of data gathering, which took place mid 2010, respondents also filled out three questionnaires. The first questionnaire gathered background information on the selected minimum income schemes, including national sources on the number of minimum income recipients. These were used to collect time series on caseloads (see section 3). Note that these data, contrary to the other

\footnotetext{
${ }^{1}$ We are grateful to Holly Sutherland for encouraging EUROMOD experts to participate in the CSB-MIPI project.
} 
information presented in this paper, are not the core focus of the CSB-MIPI project. Therefore, these national data are not fully comparable. (For a discussion on the limits of administrative data on social assistance caseloads, see De Deken \& Clasen, 2011.)

The other questionnaires focused on, respectively, i) the conditionality of minimum income benefits, and ii) policy measures implemented after the onset of the crisis that affected net disposable income of minimum income recipients. This crisis questionnaire explicitly focused on the first round crisis measures taken between 2008 and mid 2010.

In Austria, Italy and Spain, the minimum income scheme is a regional responsibility. The CSB-MIPI database contains information for respectively the regions Vienna, Milan and Catalonia. In Sweden and Norway, municipalities have a large degree of autonomy. The CSB-MIPI database provides information for Stockholm and Oslo. In the United States, the states are allowed to implement their own assistance schemes. Moreover, they have considerable autonomy in administering the federal minimum income schemes (SNAP, TANF). CSB-MIPI contains information on benefit levels and policy measures in the states Nebraska, New Jersey and Texas. More information on the methodology and content of the CSB-MIPI dataset can be found in Van Mechelen et al. (2011).

\section{Impact of the crisis on the number of social assistance recipients ${ }^{2}$}

The current crisis has brought an increase in unemployment in much of Europe. Some countries were especially hard hit, with unemployment more than doubling in Spain, Latvia, Ireland, Estonia and Lithuania (see Figure 1).

Figure 1. Quarterly unemployment rates, selected EU countries, 2007Q1 - 2011Q1

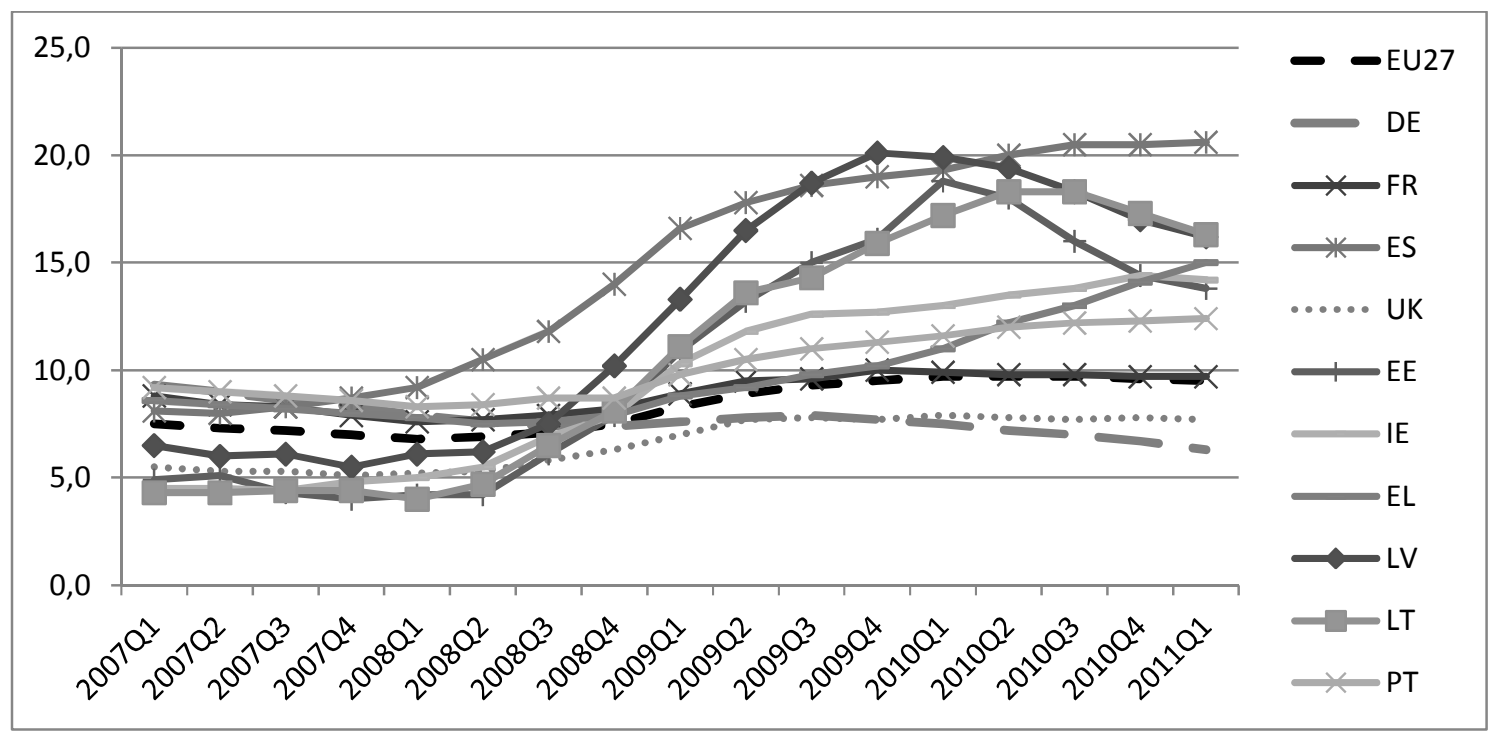

Source: (Eurostat, 2011)

\footnotetext{
${ }^{2}$ The current section draws on national data. Although these data are not fully comparable (for a detailed discussion see De Deken en Clasen (2011)), no feasible alternative is currently available. The scope of this section is limited to the countries for which data was available.
} 
Rising unemployment has led to increased reliance on benefits (OECD, 2011). Although unemployment insurance (UI) schemes are supposed to bear the brunt of this burden, some have warned that the rise of atypical jobs and the declining generosity of UI schemes in recent years, will most likely result in increased reliance on minimum income schemes (Immervoll, 2009).

Relative increases in social assistance caseloads did follow to a large extent changes in unemployment in the first crisis years. After a decline, or at least a stagnation of minimum income receipt by the mid 2000s, a sudden and vast relative increase of social assistance caseloads is observed in most countries between 2008 and 2009. The number of social assistance recipients rose with approximately $10 \%$ in Belgium, Finland, the Netherlands, Norway and Sweden. Somewhat larger increases happened in Luxembourg and the US states. The largest increases occurred in Spain (Catalonia), Lithuania, Ireland and the United Kingdom, where the number of minimum income recipients nearly doubled. This overall image is confirmed by the joint report on social protection and social inclusion of 2010, that presents the situation in Austria, the Czech Republic, Denmark, the Slovak Republic, Portugal and Latvia. The increase in social assistance recipients from 2008 to 2009 amounts to more or less $11 \%$ in Austria and the Czech Republic and $16 \%$ in Portugal, while also the remaining countries show increases (European Commission, 2010). In Germany, unemployment as well as social assistance recipiency rates remained stable.

Figure 2 presents recent trends in the number of minimum income recipients relative to the working age population ${ }^{3}$. The figure adds nuance to the large percentage rises mentioned. For instance, despite the minimum income caseload nearly doubling in Catalonia, the minimum income scheme remains marginal, providing benefits to a mere $0.4 \%$ of the working age population in 2009. Large increases occurred mainly in those countries where the minimum income scheme already played a larger role in the welfare state to begin with. Lithuania seems to be an exception.

The largest increases happened in Finland (though only within the social assistance scheme, and not in the categorical labour market subsidy ${ }^{4}$ ), Ireland, Lithuania, the United Kingdom and the three US states, and, more limited, in Luxembourg and Sweden. These countries had a relatively large minimum income caseload already before the crisis, because of the more prominent role of minimum income provision there. The number of minimum income recipients thus did not only increase substantially in those countries where the scheme fills the gap of a residual unemployment insurance scheme (such as in the United Kingdom and Ireland), but also increased starkly in countries where the minimum income scheme acts as a top-up to low wages and social security benefits (as in Finland and Luxembourg).

\footnotetext{
${ }^{3}$ One could discuss the validity of the denominator "working age population" (here: those aged 15-64 years). In some countries, minors or persons under a certain age are not eligible for social assistance. Also, persons above pensionable age may receive benefits from the same scheme as working aged recipients in some countries.

${ }^{4}$ The labour market subsidy provides benefits to the specific target group of able-bodied working aged persons without a job and not eligible for unemployment insurance benefits. Social assistance is the general social safety net. However, social assistance tops up various benefits, such as the labour market subsidy. Therefore, both are presented here. For more information, see Van Mechelen and Marchal, forthcoming.
} 
Figure 2. The number of social assistance recipients relative to the working age population, selected EU countries, 2000 - 2010

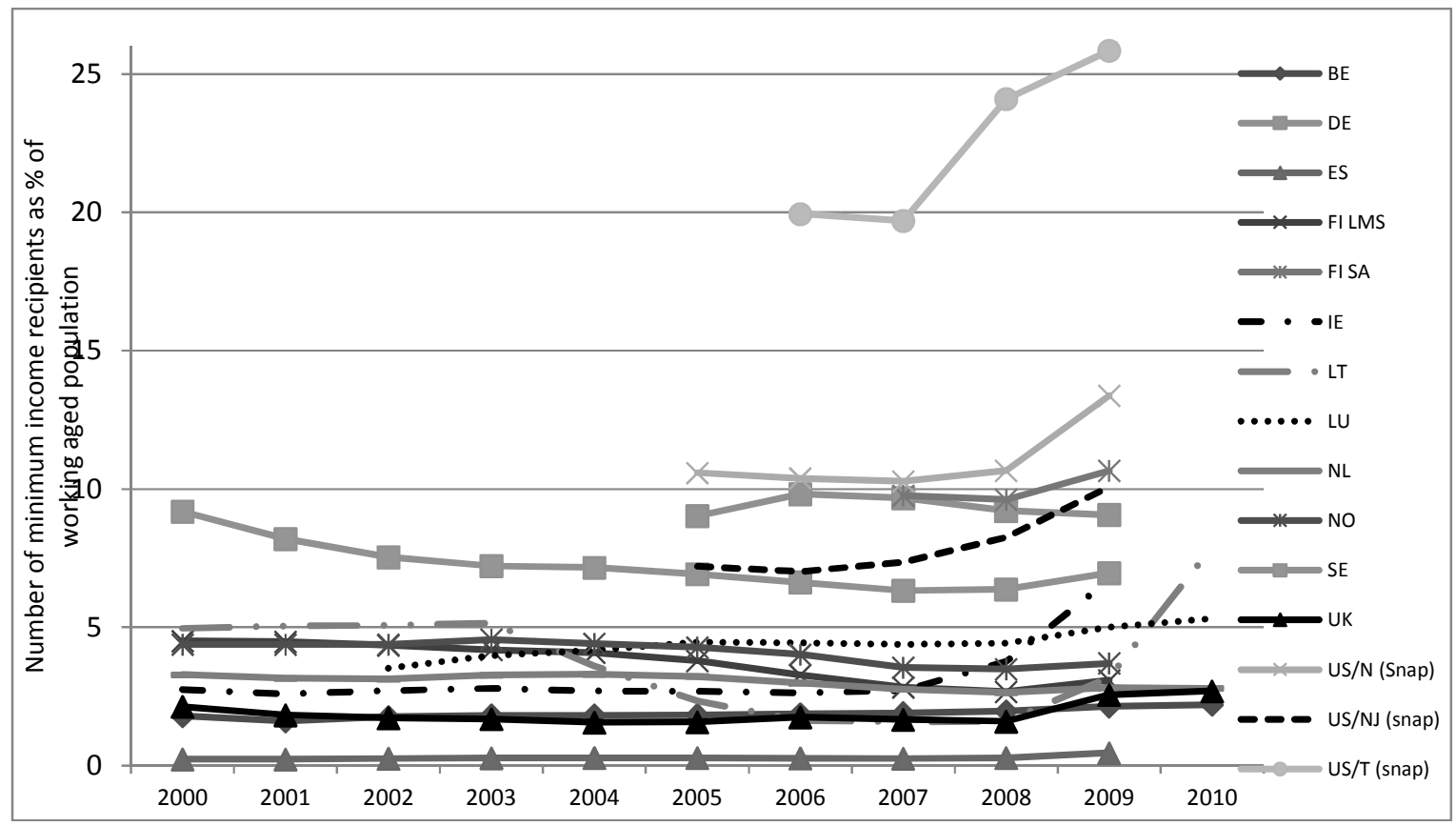

Note: LMS: labour market subsidy, SA: social assistance; N: Nebraska, NJ: New Jersey, T: Texas

Sources: (Bundesagentur für Arbeit, 2010; Centraal Bureau voor de Statistiek, 2011; Department for work and pensions, 2011; Department of social protection; Eurostat, 2011; Financial Supervisory Authority \& Social Insurance Institution, 2010; Food Research and Action Center, 2011; Generalitat de Catalunya, 2010; Idescat, 2011; POD Maatschappelijke Integratie, 2011; Service Nationale d'Action Sociale, 2011; Socialstyrelsen, 2011; Statistics Norway, 2011; Statistikos departamentas, 2011; U.S. Census Bureau, 2011)

All in all, there are indications that social assistance schemes have grown in importance during the crisis. This increased relevance calls for an assessment of the impact of crisis measures on their capacity to protect citizens against poverty.

\section{Impact of the crisis on the level of social assistance benefits}

The most important objectives of minimum income protection is the alleviation of poverty (Hölsch \& Kraus, 2004; Nelson, forthcoming). A relatively straightforward way to gauge the potential of minimum income schemes to protect against poverty is to look at benefit levels. Various studies have documented the general inadequacy of minimum income benefits in years prior to the crisis (Cantillon, et al., 2004; Nelson, forthcoming; Pfeifer, et al., 2011). In most countries, minimum income benefits have eroded substantially over the past decades relative to various indicators. In a large number of countries minimum income benefits have not kept pace with average living standards (as proxied by trends in average wages and median equivalised income). Especially during the $90 \mathrm{~s}$, benefit packages did not maintain their purchasing power in some countries (Cantillon, et al., 2004; Nelson, forthcoming; Van Mechelen \& Marchal, forthcoming).

The following subsections discuss how the crisis measures, where they were implemented, have impacted on the protective capacity of minimum income schemes. 
First, we assess changes in gross benefit levels. Though the actual living standard of minimum income recipients is best captured by their net disposable income, gross minimum income benefits determine to a large extent disposable income. Moreover, the time series data we have available allow us to set changes in gross benefit levels against previous trends, bringing to light whether the crisis has led to a change in policy. Trends in gross benefits are assessed against different indicators, including trends in consumer prices and gross average wages.

However, governments have far more tools at their disposal to influence the protective capacity of minimum income schemes. Net income packages of minimum income recipients are determined by many factors, including taxes and tax credits, social security contributions, child benefits and other supplements, such as housing allowances. Moreover, the generosity of a minimum income also effectively depends on the strength of the means-test or the duration of the benefit. Thus, the second part of this section looks at how measures taken during the first phase of the crisis have affected these components.

Finally, we ask whether minimum income protection provisions effectively provide adequate protection against poverty, as it is currently measured in the EU.

\subsection{Gross social assistance benefits}

Trends in gross benefits are generally assessed against increases in prices (Pfeifer, et al., 2011) or against indicators reflecting the development of overall living standards (Cantillon, et al., 2004; Van Mechelen, Marx, Marchal, Goedemé, \& Cantillon, 2010). This paper also presents the real benefit trends, as well as gross benefit trends relative to a benchmark for average living standard. Moreover, since the crisis has impacted on the denominators, we present trends in nominal values as well.

Table 2 presents the yearly percentage change in nominal gross social assistance benefit levels. In the years before the crisis, countries steadily increased benefits. Exceptions are the Czech Republic, where nominal gross benefits for couples decreased by $26 \%$ in 2007, and the Slovak Republic, where benefit levels more than halved in 2004. In both countries, declines were caused by far-reaching reforms of the social assistance scheme. The Czech reform split the minimum income scheme into a separate housing allowance and social assistance scheme. Since most social assistance recipients still apply for housing allowances under the new scheme, effects on net disposable income are more moderate. The Slovak reform cut the minimum income benefit to a (very) low base amount, that can be topped up by additional conditional benefits.

Table 2 shows that the growth of gross social assistance benefits generally did not halt after the onset of the crisis. In Latvia, Romania and the United Kingdom, gross benefits increased even more in the first crisis years than before. However, some countries did not maintain growth rates later on in the crisis. For instance, in Austria (Vienna), growth of nominal benefits decelerated in 2010 as compared to the previous decade. Similar decelerations have taken place in the Netherlands, Lithuania, Luxembourg, Portugal and Spain (Catalonia).

Changes in benefit levels during the crisis are especially remarkable in Estonia and Ireland. Growth of social assistance benefits had halted in Estonia already in 2008, after some strong nominal increases in the previous years. Only Ireland cut minimum income benefits in 2010. For both countries, this was an attempt to control state finances in response to the crisis. 
Table 2. Year-to-year nominal change of gross social assistance benefit level, in \%, couple

\begin{tabular}{|c|c|c|c|c|c|}
\hline & $00-06^{a}$ & '06 - '07 & '07 - '08 & '08 - '09 & '09 - 10 \\
\hline$\overline{\mathrm{AT}}$ & 2,8 & 2 & 3 & 4 & 1 \\
\hline BE & 2,9 & 3 & 6 & 4 & n.a. \\
\hline BG & n.a. & n.a. & 0 & 18 & n.a. \\
\hline $\mathrm{CZ}$ & 1,1 & -26 & 0 & 0 & n.a. \\
\hline DE & 3,7 & 1 & 2 & 2 & n.a. \\
\hline DK & 2,8 & 2 & 3 & 3 & 4 \\
\hline EE & 8,3 & 20 & 11 & 0 & n.a. \\
\hline ES & 3,4 & 9 & 4 & 3 & 1 \\
\hline $\mathrm{FI}^{*}$ & 2,1 & 1 & 2 & 3 & 5 \\
\hline FR & 1,8 & 2 & 2 & 2 & 1 \\
\hline IE ${ }^{*}$ & 9,5 & 12 & 6 & 3 & -4 \\
\hline IT & 3,0 & 2 & 2 & 3 & n.a. \\
\hline LT & n.a. & 32 & 39 & 23 & 0 \\
\hline LU & 3,3 & 4 & 2 & 4 & 0 \\
\hline LV & n.a. & 13 & 0 & 37 & 8 \\
\hline NL & 3,5 & 3 & 2 & 1 & 1 \\
\hline NO* & 2,0 & 6 & 7 & 3 & n.a. \\
\hline PT & 5,5 & 3 & 3 & 3 & 1 \\
\hline RO & 53,1 & 4 & 5 & 8 & 15 \\
\hline SE & 1,9 & 3 & 4 & 4 & n.a. \\
\hline SI & 12,0 & 2 & 4 & 4 & 2 \\
\hline $\mathrm{SK}^{*}$ & $-12,5$ & 6 & 2 & 5 & 3 \\
\hline UK & 1,6 & 3 & 2 & 6 & 2 \\
\hline
\end{tabular}

${ }^{a}$ : average annual nominal change in gross social assistance benefit

Note: data for IE and FI refer to gross social assistance benefits for a single; FI (Labour Market Subsidy); NO and SK: average annual nominal change over period 2002-2006; PL, HU: n.a.; EL: no minimum income scheme.

Source: CSB-MIPI (Van Mechelen et al., 2011); (European Commission, 2011)

Table 3 shows that during the years prior to the crisis, gross benefits generally maintained their purchasing power. In more than a few countries, benefit levels even increased (somewhat) more than consumer prices. Nevertheless, there are some important exceptions, mainly in those countries where no automatic indexation procedure exists. This is the case in, for instance, Bulgaria and Latvia. However, discretionary indexation not necessarily leads to erosion. Benefit levels increased faster than consumer prices in, for instance, Ireland, Lithuania and Estonia, due to substantial hikes enacted by the government (see also Van Mechelen and Marchal, forthcoming).

Immediately after the onset of the crisis, real benefits generally increased. In some countries, these increases are substantially above previous growth rates, especially in the Eastern European countries Bulgaria and Latvia. The substantial hikes in Lithuania had already started before the onset of the crisis. The deceleration in nominal growth seen for 2009-2010 (see Table 2), has led in some countries to a small loss in purchasing power. However, this decrease seems very much in line with trends in real benefits in pre-crisis years. 
Table 3. Year-to-year percentage change of gross social assistance benefit level, 2010 prices (HICP), couple

\begin{tabular}{|c|c|c|c|c|c|}
\hline & $00-06^{a}$ & '06 - '07 & '07 - '08 & '08 - '09 & '09- 10 \\
\hline AT & 1 & -1 & 0 & 3 & 0 \\
\hline BE & 1 & 1 & 2 & 4 & 0 \\
\hline BG & n.a. & n.a. & -11 & 15 & n.a. \\
\hline CZ & -1 & -28 & -6 & -1 & n.a. \\
\hline DE & 2 & -1 & -1 & 2 & n.a. \\
\hline DK & 1 & 1 & -1 & 2 & 1 \\
\hline EE & 4 & 12 & 0 & 0 & n.a. \\
\hline ES & 0 & 6 & 0 & 3 & -1 \\
\hline $\mathrm{FI}^{*}$ & 1 & 0 & -2 & 1 & 3 \\
\hline FR & 0 & 0 & -2 & 1 & -1 \\
\hline $\mathrm{IE}^{*}$ & 6 & 9 & 3 & 5 & -3 \\
\hline IT & 1 & 0 & -2 & 3 & n.a. \\
\hline LT & 4 & 25 & 25 & 18 & -1 \\
\hline LU & 0 & 1 & -2 & 4 & -3 \\
\hline LV & 8 & 2 & -13 & 33 & 9 \\
\hline NL & 1 & 1 & 0 & 1 & 0 \\
\hline NO* & 0 & 6 & 3 & 1 & n.a. \\
\hline PT & 2 & 1 & 0 & 4 & 0 \\
\hline RO & 30 & -1 & -3 & 3 & 8 \\
\hline SE & 0 & 1 & 1 & 2 & n.a. \\
\hline SI & 6 & -1 & -2 & 3 & 0 \\
\hline $\mathrm{SK}^{*}$ & -17 & 4 & -2 & 4 & 3 \\
\hline UK & 0 & 1 & -1 & 4 & -2 \\
\hline
\end{tabular}

a: average annual nominal change in gross social assistance benefit

Note: data for IE and FI refer to gross social assistance benefits for a single; FI (Labour Market Subsidy); NO and SK: average annual nominal change over period 2002-2006; PL, HU: n.a.; EL: no minimum income scheme.

Source: CSB-MIPI (Van Mechelen et al., 2011); (European Commission, 2011)

Figure 3 presents trends in minimum income benefits relative to average living standards, proxied here by the gross average wage. For the sake of presentation, countries are grouped by the extent of erosion of benefit levels during the preceding decade (2000-2007).

Figure 3 shows that during the previous decade, benefit levels have eroded relative to overall prosperity of society in more than half of the countries in our sample. Only Ireland, Portugal, Spain (Catalonia), Belgium, the Netherlands, Germany and Austria (Vienna) succeeded in maintaining or improving relative gross social assistance benefits. However, these countries had allowed a substantial erosion of gross benefit levels in the 1990s, as documented in previous research (Cantillon, et al., 2004, see also figure A in appendix). Romania and Slovenia had in 2007 benefit levels that were, relative to average wages, far more generous than at the start of the decade, though this was mostly the consequence of a one-time reform, followed by subsequent erosion.

What happened after the onset of the crisis? We do not see a common response. In the countries where gross benefits eroded most during the past decade, in the Czech Republic and in Finland, this erosion continued during the crisis. Benefit levels stagnated in the Slovak Republic. On the other hand, 
strong rises in gross benefits relative to gross average wage occurred in the United Kingdom, Lithuania, and Estonia. In the latter country, gross average wages were substantially affected by the crisis.

In those countries where erosion was limited over the past decade, again, a mixed picture emerges. In most countries, crisis measures did not counter the gradual erosion of previous years. However, in Lithuania, strong nominal increases ensured that benefits grew over and above average wages. Although these increases had already started in 2006, their pace accelerated during the crisis. In Italy (Milan), gross benefits increased somewhat at the start of the crisis, although the impact is limited.

Both in Slovenia and in Romania the crisis came after years of benefit erosion. In both countries, this erosion was countered. Other increases occurred in Belgium, Ireland and Germany ${ }^{5}$. Yet in the first two countries this increase seems to be in line with earlier developments. On the other hand, in the Netherlands and Portugal, gross benefits eroded marginally.

All in all, gross social assistance benefits have not suffered serious blows during the crisis. In nominal as well as real terms, increases are to be observed, especially immediately after the start of the crisis. In relative terms, increases of gross benefit levels are in line with earlier trends for most countries. We do not observe a general break in trends or exceptional reactions, except for the nominal decrease of social assistance benefits in Ireland, and the strong increases in Lithuania and Latvia. It remains to be seen whether the latter countries have indeed embarked on a new, more generous path. Absence of nominal increases in 2009-2010 (Lithuania) and 2010-2011 (Latvia) suggest this is not the case. Other policy measures impacting on the income of social assistance recipients do not directly appear in time series on gross benefits. Governments may well be inclined towards alternative measures, as retrenchment in gross benefit levels is rather visible and potentially controversial. Thus the next section asks whether governments used other routes to implement changes in minimum income protection systems.

\footnotetext{
${ }^{5}$ Not in figure.
} 
Figure 3. Trends in gross social assistance benefits for a couple relative to gross average wages, $2000-2009 / 2010,2000=100 *$

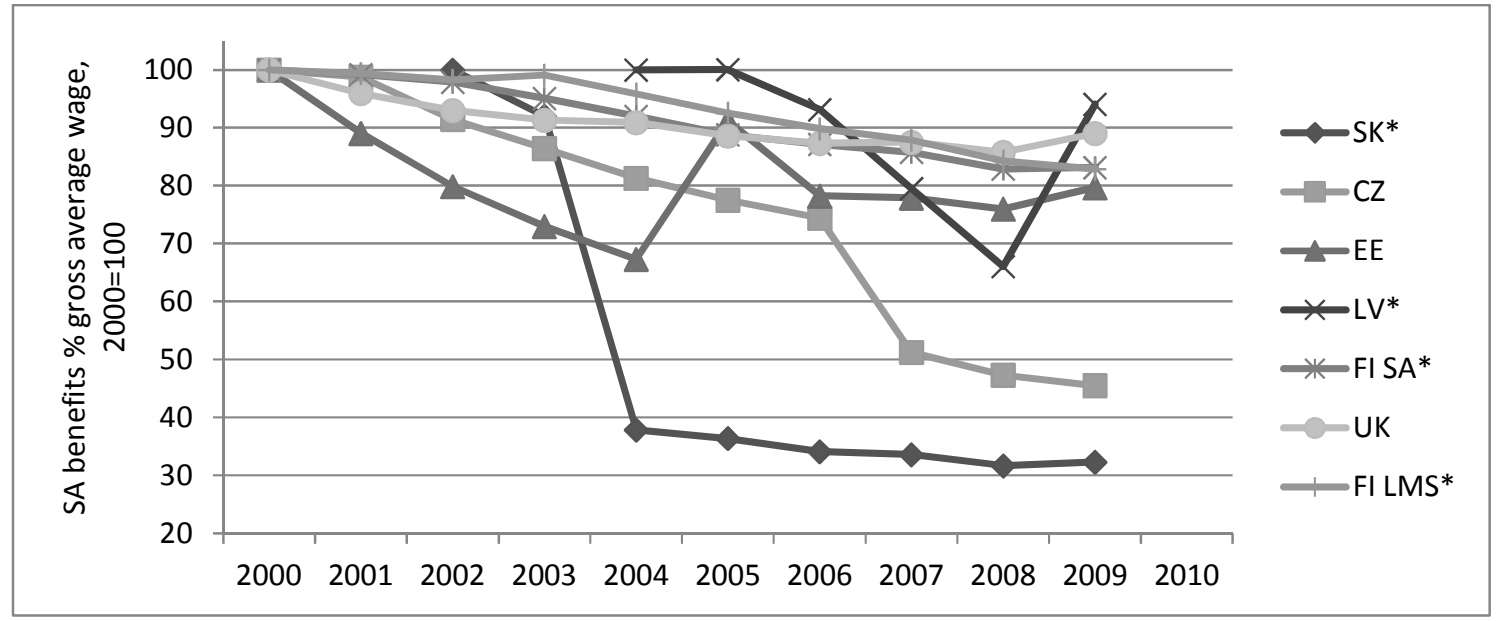

*SK: 2002=100; LV: 2004=100. FI: gross benefit for a single.

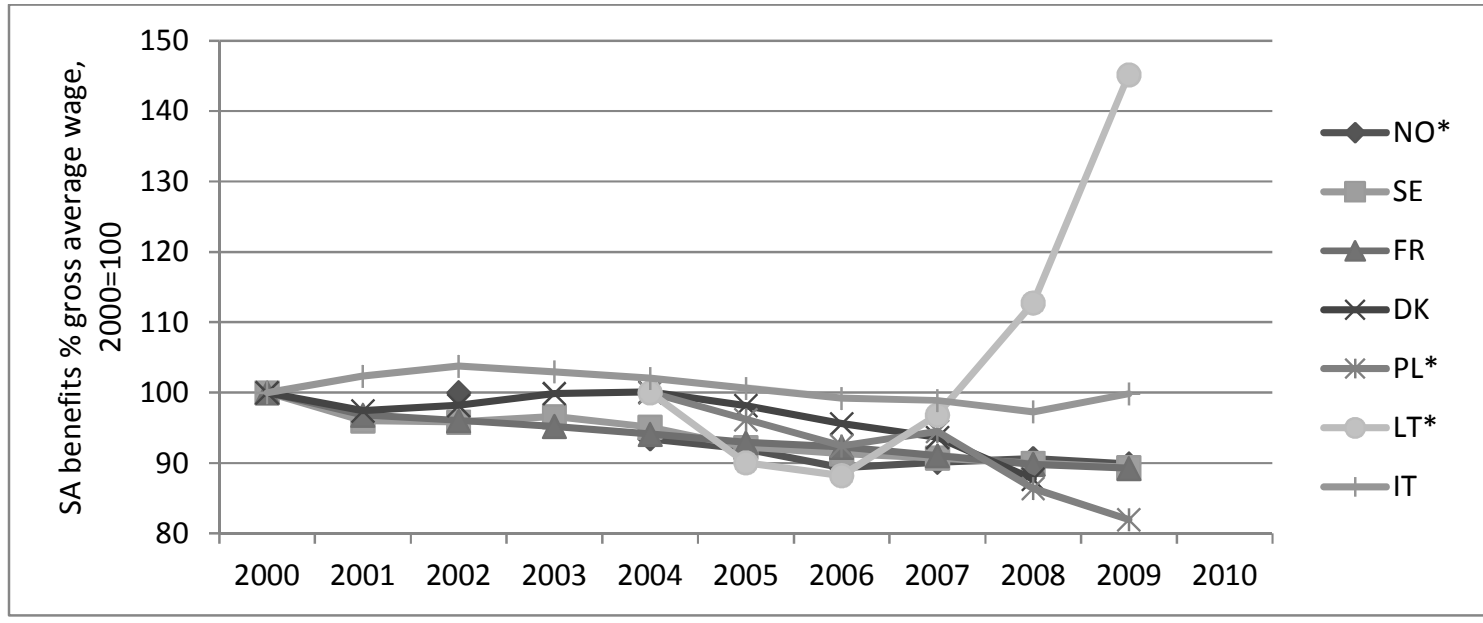

*NO: 2002=100; PL and LT: 2004=100

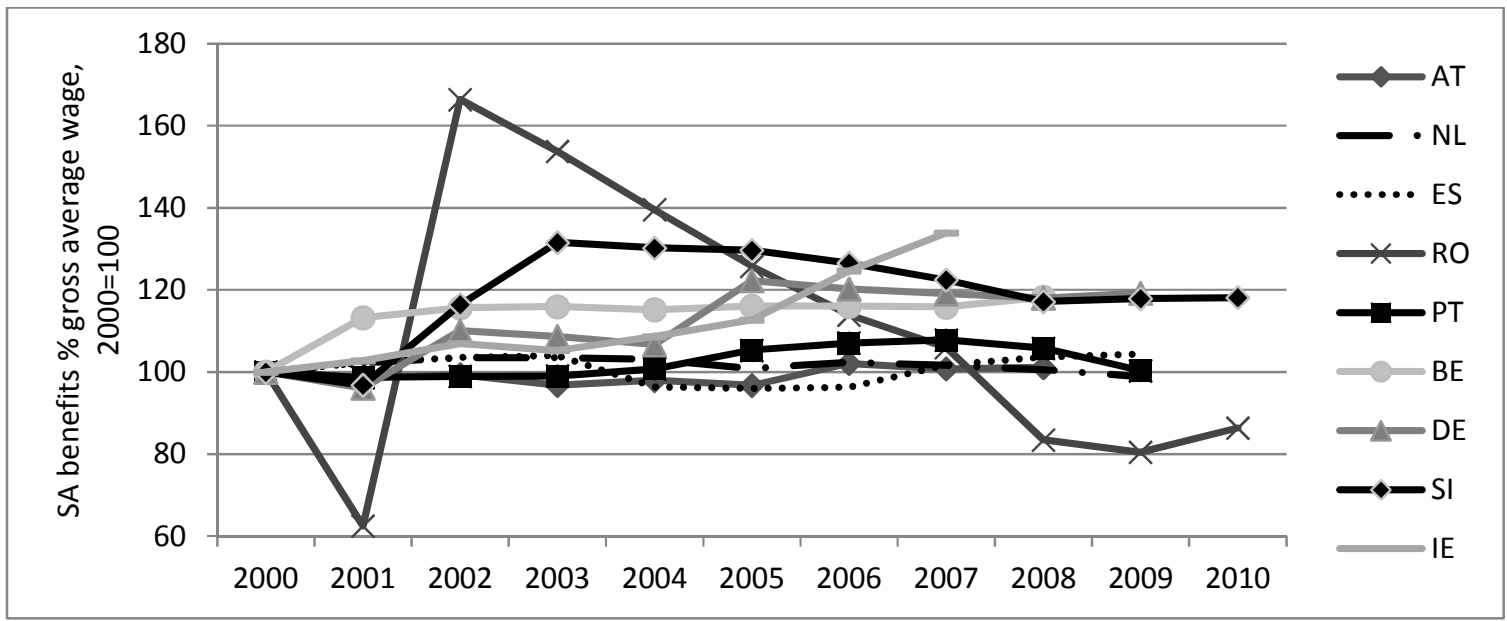

*countries are grouped according to former evolution. (large erosion, minor erosion, equal or increase) Source: CSB-MIPI (Van Mechelen et al., 2011); (European Commission, 2011), (Eurostat, 2011) 


\subsection{Net disposable incomes of social assistance recipients}

Table 4 shows policy changes affecting net disposable income packages of minimum income recipients, including policy changes affecting child benefits, taxes, social security contributions and (also) gross benefit levels. It also includes measures affecting the generosity of income packages in more indirect ways, by changing time limits or income criteria. Please note that we do not include regular indexation.

Table 4 splits policy measures in those taken before June 2009 and those issued between July 2009 and mid $2010^{6}$. This division is caused by the set-up of our data-gathering effort, with policy changes taken before mid 2009 still reflected in the model family simulations for $2009^{7}$. If available, more detailed information on the implementation date is included. Therefore, the information provided by national respondents (see section 2) is supplemented with information from MISSOC and the OECD Benefit and Wages country reports. It is possible that not all the measures reported in the table are genuine crisis measures.

Countries that did not report measures affecting net disposable income of social assistance benefits are Denmark, Spain, Finland, Italy, the Netherlands, Sweden, Slovenia and Slovakia ${ }^{8}$. As for Denmark and Italy, possibly in-kind benefits or services helped to cushion the impact of the crisis. In Finland, the crisis effectively prevented expected increases, but no cuts were enacted.

In general, most countries took measures that raised the net disposable incomes of social assistance recipients, either by directly raising social assistance benefits (BE, BG, LT, LV, IE, NO, RO and the UK) or by introducing a supplementary allowance (Luxembourg). Also in the US, benefits under the Supplemental Nutritional Assistance Program (SNAP, food stamps) were increased by $13.6 \%$. Immervoll and Llena-Nozal (2011) report similar measures for other OECD countries. A number of countries chose to increase child related benefits (AT, DE, IE, LT, PT, RO, UK). France awarded oneoff measures to particular groups of the low-income population. One of these measures was conditional upon having children of school-age. Slovenia awarded a one-time supplement to its minimum income recipients during the crisis.

Most of these expansionary anti-crisis measures were taken before or during the summer of 2009 . Only in Latvia, Romania and the United Kingdom, increases of gross benefits apart from regular indexation were enacted more recently. This lack of new measures during 2010 may be due to a wish or a need to limit expenditures, at a time when the budgetary challenges of the crisis were gaining more attention.

\footnotetext{
${ }^{6}$ Other presentations of these crisis measures are conceivable. For instance, Hemerijck (Hemerijck, 2012) argues that the perception and nature of the crisis changed by the end of 2009 , turning from a recession into a budgetary crisis.

${ }^{7}$ See Figure 4 on the adequacy of net benefit levels.

${ }^{8}$ Greece is not included since no general minimum income scheme exists in this country.
} 
Table 4. Overview of measures affecting net disposable income at social assistance since 2008 until mid 2010

\begin{tabular}{|c|c|c|}
\hline & After onset crisis (until June 2009) & More recent measures (July 2009-Mid 2010) \\
\hline AT & Net: Universal rise of child tax credit and child benefit & $\begin{array}{l}\text { Gross: September 2010: new minimum income benefit } \\
\text { scheme, that presumably benefits social assistance } \\
\text { recipients }\end{array}$ \\
\hline BE & $\begin{array}{l}\text { Gross: } 2008: \text { rise by } 2 \% \\
\text { 2009: rise by } 2 \%\end{array}$ & \\
\hline$B G$ & $\begin{array}{l}\text { Gross: 2009: rise by } 18.2 \% \\
\text { 1/7/2008: Stricter time limit: duration limited to } 12 \\
\text { months (previously } 18 \text { months)* }\end{array}$ & \\
\hline $\mathrm{CZ}$ & Gross: decrease after 6 months of benefit receipt * & \\
\hline $\mathrm{DE}$ & & $\begin{array}{l}\text { Net: July 2009: temporary increase of child related } \\
\text { lump-sum benefits in determination of the level of the } \\
\text { Arbeitlosengeld II }\end{array}$ \\
\hline EE & Net: abolishment of school allowance & \\
\hline FR & $\begin{array}{l}\text { Net: one-off measures (lump-sum benefits) for } \\
\text { certain groups of low-income households }\end{array}$ & \\
\hline $\mathrm{HU}$ & $\begin{array}{l}\text { Gross: Rise, but conditional upon participation in } \\
\text { employment programme* }\end{array}$ & $\begin{array}{l}\text { Gross: decline: January 2010: only one adult per } \\
\text { household eligible for higher benefit } \\
\text { Net : January 2010: decreased eligibility period for child } \\
\text { benefit }\end{array}$ \\
\hline IE & $\begin{array}{l}\text { Gross: rise } \\
\text { Net: increase in support for lone parent families }\end{array}$ & $\begin{array}{l}\text { Gross: decline (January 2010) } \\
\text { Net: Reduction of child benefits and support for lone } \\
\text { parent families }\end{array}$ \\
\hline LT & $\begin{array}{l}\text { Gross: January and August 2008: increase of state- } \\
\text { supported income from LTL } 235 \text { to LTL } 350 \\
\text { Net: } 2008 \text { : laxer means-test (exclusion of certain } \\
\text { income sources) } \\
\text { July 2008: increase in child benefit } \\
\text { 2009: child benefit has become means-tested. }\end{array}$ & $\begin{array}{l}\text { Net:January 2010: income limit for means-tested child } \\
\text { benefit was halved, from } 1050 \text { LTL to } 525 \text { LTL. }\end{array}$ \\
\hline LU & $\begin{array}{l}\text { Net: - Introduction of cost of living allowance } \\
\text { - Linear increase of tax brackets }\end{array}$ & \\
\hline LV & Gross: January 2009: rise & $\begin{array}{l}\text { Gross: October 2009: rise } \\
\text { Net: - July 2009: temporary decline of child benefit } \\
\text { - January 2010: Withdrawal of ceiling of benefits } \\
\quad \text { (in case of large families) } \\
\text { July 2009: abolishment of time limits } \\
\text { December 2009: Means-test: less strict }\end{array}$ \\
\hline NO & Gross: rise of benefits in national guidelines by $5 \%$ & \\
\hline $\mathrm{PL}$ & & Gross: Envisaged indexation did not occur \\
\hline PT & $\begin{array}{l}\text { Net: increase of child benefits for low income } \\
\text { categories }\end{array}$ & $\begin{array}{l}\text { Net: June 2010: end of complementary support } \\
\text { Stricter means test }\end{array}$ \\
\hline RO & $\begin{array}{l}\text { Gross: rise } \\
\text { Net: child benefit extended }\end{array}$ & $\begin{array}{l}\text { Gross: rise + financing fully covered by national } \\
\text { government } \\
\text { Net: lower eligibility threshold for heating allowance } \\
\text { (July 2009) }\end{array}$ \\
\hline SI & & August 2009: one-off supplement \\
\hline UK & $\begin{array}{l}\text { Gross: increase (April 2009) } \\
\text { Net: rise of child tax credit and child benefit }\end{array}$ & $\begin{array}{l}\text { Gross: increase (April 2010) } \\
\text { Net: rise of child tax credit and child benefit }\end{array}$ \\
\hline US & Gross: increase of SNAP benefits & \\
\hline
\end{tabular}

\footnotetext{
* Respondent indicates that the measure was already legislated before the onset of the crisis: no crisis measure.
}

Source: CSB-MIPI (Van Mechelen et al., 2011), (European Commission, 2011), (OECD, 2010)

On the other hand, "negative" measures were remarkably absent immediately after the onset of the crisis. Estonia abolished a school allowance, whereas Lithuania combined a considerable increase of gross social assistance benefits with making the child benefit means-tested out of budgetary 
considerations. Also the Czech Republic implemented a measure negatively impacting on net disposable income. However, both in the Czech Republic and Hungary, the measures enacted in the first crisis years were no genuine crisis measures, but were part of more far-reaching reforms legislated before the onset of the crisis. In the Czech Republic, the reform stipulated that after six months of benefit receipt, gross benefits are diminished, unless one has participated in active labour market programmes. In Hungary, a new benefit was introduced in 2009 for those of working age that are able to work. Adults receive higher (individual) benefits, but benefit receipt is made conditional upon participation in ALMPs. The Bulgarian tightening of time limits also appears part of a broader government strategy, initiated in 2006, taking a tougher line on minimum income recipients (Bogdanov \& Zahariev, 2009).

In a later stage of the crisis negative measures became more common. Although Romania and Latvia introduced already in the summer of 2009 some minor cuts, these were still followed by additional increases in gross benefits. These increases were far from trivial (see section 4.1), whereas the negative measures, a decrease of the universal child benefit in Latvia and a lower eligibility threshold for a heating allowance in Romania, were relatively moderate. In Poland, the planned three-yearly indexation of benefit thresholds was skipped. In 2010, four more countries implemented measures that had a negative impact on net income of minimum income recipients. The Irish government cut gross social assistance and child benefits. In Lithuania, the earlier introduced means-test for child benefits was tightened. The Portuguese government tightened access to minimum income benefits. In Hungary, a measure introduced by the 2009 reform, was partly withdrawn. From 2010 on, only one adult per household can qualify for a higher benefit.

These retrenchment measures are relatively diverse. A number of countries effectively diminished or abolished benefits (although only one country has gone as far as to cut minimum income benefits), whereas other countries have made access to benefits harder by introducing or strengthening meanstests. All in all, reductions of net disposable income are mostly not directly caused by changes in the minimum income scheme, but are achieved more indirectly, through the child benefits scheme and, in a less visible way, by lowering eligibility thresholds and skipping indexation.

\subsection{How well do minimum income protection provisions protect against poverty?}

We now turn to the question of how adequate minimum income protection provisions are in protecting against poverty. In its resolution of 20 October 2010 on the role of minimum income in combating poverty and promoting an inclusive society in Europe, the European Parliament 'takes the view that adequate minimum income schemes must set minimum incomes at a level equivalent to at least $60 \%$ of median income in the Member State concerned' (European Parliament, 2010). The European poverty line is thus put forward as a reference point to assess the adequacy of benefit levels, despite the fact that the debate on whether this operationalisation of poverty is appropriate has revived recently as a result of the enlargement of the EU (Fahey, 2007).

Figure 4 uses the EU poverty line to assess the adequacy of benefit levels. This figure includes all the measures mentioned in the first column of Figure 4, i.e. the measures implemented before the end of June $2009^{9}$. The figure shows that social assistance benefit packages (including housing allowances

\footnotetext{
${ }^{9}$ The Hungarian reform is the only exception.
} 
and child benefits but excluding in-kind benefits and associated rights) are above the European poverty line only in Ireland (for single person households) and in Denmark (for couples). It remains to be seen how the recent cuts in Irish minimum income benefits will influence this ranking. In the other EU Member States social assistance benefit packages are insufficient to protect benefit recipients and their households against poverty ${ }^{10}$.

In the Netherlands, Luxembourg, Belgium, Austria (Vienna), Germany, France, but also in Latvia benefit levels are between $40 \%$ and $50 \%$ of median equivalent household income, although there is generally considerable variation across family types. In the majority of countries social assistance payments are usually below $40 \%$ of median income, especially for households without children. This is even the case in rich Member States such as Finland, Sweden, Norway and the United Kingdom. In the Slovak Republic, Estonia, Bulgaria and Romania, benefit levels are typically set below half the poverty line. Following a different methodology, Figari et al. (2011) also points to the general inadequacy of minimum income schemes.

Figure 4 also shows that the countries where measures have been taken negatively affecting net disposable incomes of minimum income beneficiaries (EE, HU, PT, PL, IE, and, more moderately: LT, RO, LV) are not uniformly among the most generous countries. Although Ireland had the most generous minimum income benefits for able-bodied working-aged persons before the cuts ${ }^{11}$, other countries, such as Estonia, find themselves at the other end of the spectrum.

\footnotetext{
${ }^{10}$ The CSB-MIPI-estimates of net social assistance benefit packages tend to provide a(n even) less favourable picture of the adequacy of assistance payments than the estimates presented in the OECD's Employment Outlook 2009. This is largely explained by the fact that the CSB-MIPI data draw on much lower housing costs. Whereas the CSB-MIPI study focuses on households with a rental costs equal to only $2 / 3$ of median rent (SILC), the OECD estimates are based on the assumption that in all countries housing costs are equal to $20 \%$ of average wage, for all family types (see Van Mechelen et al, 2011).

${ }^{11}$ In fact, this leading position was used to defend these cuts, according to Dukelow (2011).
} 
Figure 4. The adequacy of net social assistance benefit packages, 2009
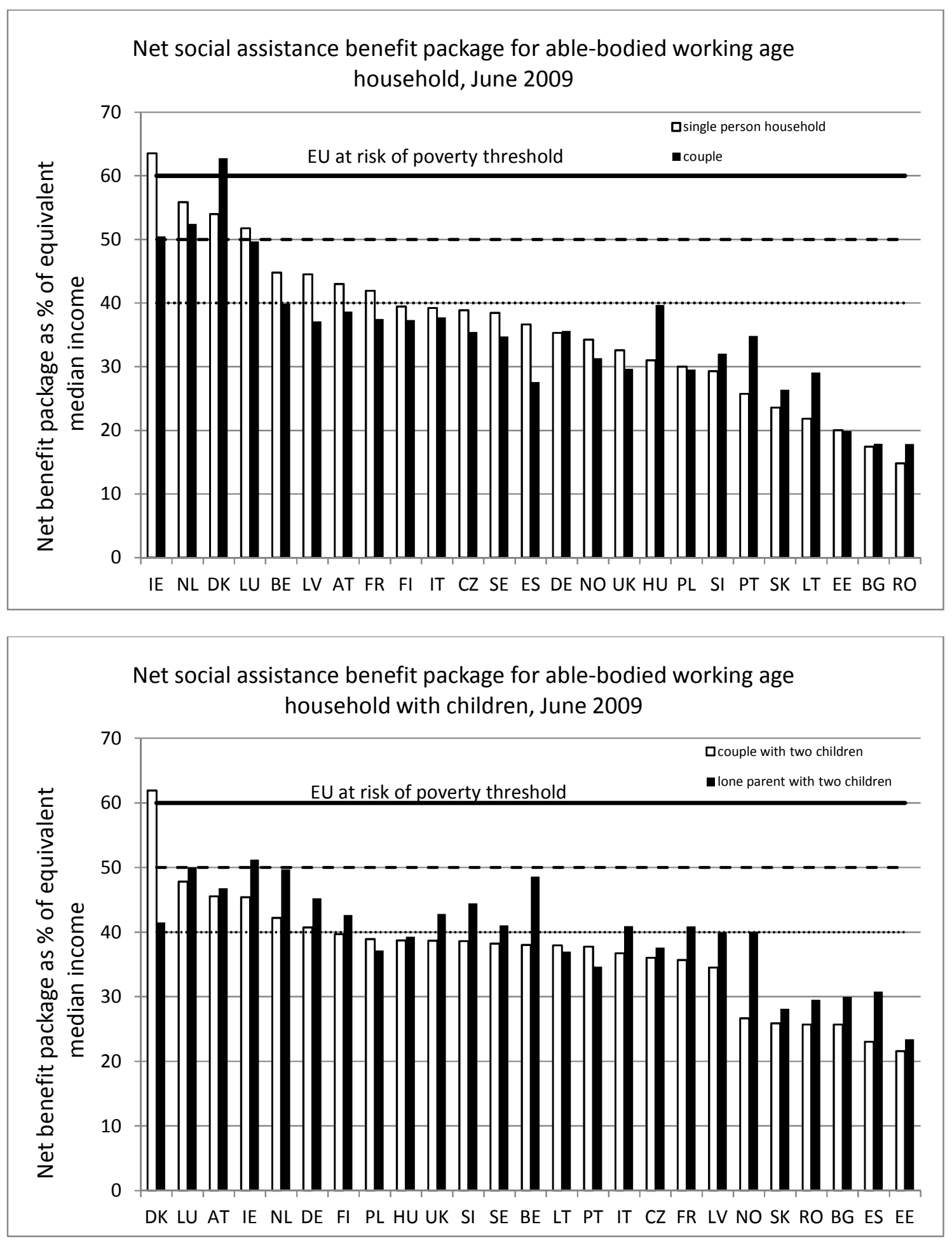

Note: In some countries, such as the US, Italy and Bulgaria, time limits apply, either formal or discretionary. In order to avoid additional assumptions, the levels displayed do not take these time limits into account.

Source: CSB-MIPI (Van Mechelen et al, 2011); (Eurostat, 2011) 


\section{Changes in behavioral requirements}

This section looks at changes in behavioral requirements as these apply to people receiving social assistance or equivalent support ${ }^{12}$. Behavioral requirements do not directly impact on the generosity of net income, but aim to regulate behavior of minimum income recipients through the use of sanctions or supportive measures (or both), possibly coupled with investments in their skills/human capital. In previous years, this aspect of minimum income schemes has gained in importance, as governments have become more focused on activation (Eichhorst \& Konle-Seidl, 2008; Weishaupt, forthcoming).

Table 5 provides an overview of changes in behavioral conditionality (and the closely intertwined social investment) measures implemented since the onset of the crisis. This table mainly describes the impact of the crisis on the legal rules applying to social assistance recipients. Differences in implementation are understandably harder to capture.

Only for a limited number of countries, our experts report changes in behavioral requirements during the crisis period under review. Even so, most of these changes were implementations of earlier legislated reforms. In only six countries, changes were reportedly implemented during the crisis period: Estonia, Finland, Latvia, Portugal, Romania and the UK. In four countries (Finland, Latvia, Portugal and the UK), active labour market measures for minimum income recipients were expanded, or participation financially encouraged. Portugal is apparently the only country that imposed harsher sanctions in case of non-compliance. Active labour market programmes were also expanded elsewhere in Europe, for instance in Ireland ${ }^{13}$, Sweden and Denmark, but it is not clear to what extent minimum income beneficiaries have benefited in these countries. (Bonoli, 2010; Chung \& Thewissen, 2011; Weishaupt, 2011).

Only in two countries, Romania and Estonia, behavioral requirements became less strict during the crisis period. However, the changes apply to a very small subset of the social assistance population (for instance in Romania: those adults caring for a handicapped child aged 16-18 years).

\footnotetext{
${ }^{12}$ The focus of the CSB-MIPI questionnaire was on regulations with regard to behavioral conditionality, thus regulating ongoing benefit receipt. Crisis measures may also have impacted on other types of conditionality, such as the means-test (see section 4.2).

${ }^{13}$ The budget of the public employment service was raised in Ireland. However, it is not clear whether this actually benefited social assistance recipients. Dukelow (2011:422) mentioned that "prior to the full unslaught of the economic crisis ... retrenchment focused on the less visible areas of conditions and entitlements". Also, according to the citizens information board, some active labour market programmes were made inaccessible by mid 2009 (Citizens information board, 2011)
} 
Table 5. Overview of changes in behavioral requirements from 2008 on until mid 2010

\begin{tabular}{|c|c|c|}
\hline & After onset crisis (until June 2009) & More recent measures (July 2009-Mid 2010) \\
\hline $\mathrm{CZ}^{*}$ & $\begin{array}{l}\text { After } 6 \text { months of SA receipt, benefit is reduced unless one } \\
\text { participates in public work or volunteer services (at least } 20 \\
\text { hours/week)* }\end{array}$ & \\
\hline EE & 1/5/2009: Less strict suitable work criterium & \\
\hline $\mathrm{FI}$ & $\begin{array}{l}\text { SA: Regulation to reduce waiting lists. More swiftly responding } \\
\text { to new demands and need of social assistance recipients. }{ }^{*}\end{array}$ & $\begin{array}{l}\text { LMS: } 1 / 1 / 2010 \text { : maximum period of participation in } \\
\text { re-employment programmes opening right to } \\
\text { supplement was increased from } 185 \text { to } 200 \text { days. } \\
\text { Activation measures that entitle to increased } \\
\text { benefits are defined more broadly. Increase of } \\
\text { activation allowance awarded upon participation in } \\
\text { activation measures. }\end{array}$ \\
\hline FR & $\begin{array}{l}\text { Introduction of rSa (june 2009): new activity requirements. } \\
\text { But: not yet visible in practice because of crisis }\end{array}$ & \\
\hline $\mathrm{HU}^{*}$ & $\begin{array}{l}\text { "Road to work": public employment organized by local } \\
\text { government for long-term unemployed and social assistance } \\
\text { beneficiaries (separate scheme with higher benefit)* }\end{array}$ & \\
\hline LV & & $\begin{array}{l}\text { Sept 2009: Introduction of new ALMP: "Work } \\
\text { practice in municipalities with a stipend" }\end{array}$ \\
\hline NL & & $\begin{array}{l}\text { 1/10/2009: investment in the young act came into } \\
\text { force: youngsters must comply to more conditions } \\
\text { in order to receive a benefit * }\end{array}$ \\
\hline PT & $\begin{array}{l}\text { January 2009: introduction of new ALMP "employment contract } \\
\text { insertion plus" }\end{array}$ & $\begin{array}{l}\text { June 2010: Offer of active labour market } \\
\text { programmes will be expanded, so as to ensure a } \\
\text { maximum waiting period of } 6 \text { months. } \\
\text { Harsher sanctions, especially in the case of fraud. }\end{array}$ \\
\hline RO & $\begin{array}{l}\text { Less strict activity requirements for adults with care } \\
\text { responsibilities }\end{array}$ & \\
\hline UK & $\begin{array}{l}\text { Expansion of active labour market programmes: } 6^{\text {th }} \text { month offer } \\
\text { (April 2009) }\end{array}$ & $\begin{array}{l}\text { Expansion of active labour market programmes: } \\
\text { "support for the newly unemployed", "Young } \\
\text { person's guarantee" and "Future job fund" (October } \\
\text { 2009) }\end{array}$ \\
\hline
\end{tabular}

*: respondent notes that this change was already legislated before the onset of the crisis.

Source: CSB-MIPI (see Van Mechelen et al., 2011)

\section{Conclusion}

This paper has dealt with two basic questions. First, how, if at all, did EU governments adjust their minimum income protection policies in response to the initial phase of the current crisis? Did that response prove to be a path-breaking event, and was there any communality in the response across the EU? Second, do minimum income schemes in the EU provide adequate protection against poverty?

As for the first question, we find a general pattern of increases in gross minimum income benefits levels across the EU during the first phase of the crisis. These hikes by and large sufficed to keep benefits in line with average living standards, be it that exceptions exist. In some countries these increases countered a trend of gradual decline during the pre-crisis years. Yet the size of the increases does not point to marked breaks in long-term trends.

In a substantial number of countries we find (additional) measures to boost the net income packages of households reliant on social assistance or equivalent minimum income support. Most frequent are (targeted) hikes in child-related benefits. Some countries have awarded one-off lump-sum benefits. 
Behavioral requirements imposed on minimum income recipients have been neither tightened nor relaxed. In a limited number of countries, activation efforts aimed at minimum income recipients have been intensified.

Although supportive measures are the general pattern during the initial phase of the crisis, some retrenchment measures are evident later on in at least a number of countries. Examples include: skipping indexation, tightening the means-test, abolishment or decrease of additional benefits (for instance child benefits). Only one country, Ireland, has actually cut minimum income benefits.

Despite a number of positive developments, net incomes of minimum income recipients continue to fall well short of the EU's at risk of poverty threshold in all but two EU countries. The size of the gap between the level of the social safety net and the poverty threshold varies across countries and family types, but it is generally quite substantial. In that sense, the fact that minimum income schemes have turned out remarkably resilient during the first crisis period offers little reason for complacence.

In the meanwhile, pressures for public spending cuts have mounted in most EU countries, in some countries to levels not seen in generations. Policy change in the direction of retrenchment seems not implausible. Both the UK and the Netherlands have already announced far-reaching reforms of their minimum income schemes. A close and continued monitoring of Europe's social safety nets seems in order. 


\section{Appendix}

\section{Table A. List of national experts}

\begin{tabular}{|c|c|c|c|}
\hline Austria & FUCHS & Michael & European Centre for Social Welfare Policy and Research, Wien \\
\hline & STANZL & Peter & City of Vienna \\
\hline \multirow[t]{2}{*}{ Belgium } & VAN MECHELEN & Natascha & \multirow[t]{2}{*}{ Herman Deleeck Centre for Social Policy (CSB), University of Antwerp } \\
\hline & MARCHAL & Sarah & \\
\hline \multirow[t]{2}{*}{ Bulgaria } & BOSHNAKOV & Venelin & University of National and World Economy, Sofia \\
\hline & DRAGANOV & Dragomir & Senior Expert Policies and Strategies, Ministry of Labour and Social Policy \\
\hline \multirow[t]{2}{*}{ Czech Republic } & MUNICH & Daniel & \multirow{2}{*}{$\begin{array}{l}\text { Center for Economic Research and Graduate Education - Economic Institute } \\
\text { (CERGE-EI), Prague }\end{array}$} \\
\hline & PAVEL & Jan & \\
\hline Denmark & ABRAHAMSON & Peter & University of Copenhagen \\
\hline Estonia & VÕRK & Andres & University of Tartu / Praxis Center for Policy Studies \\
\hline \multirow[t]{2}{*}{ Finland } & KANGAS & Olli & \multirow[t]{2}{*}{ Kela, Helsinki } \\
\hline & HAATAJA & Anita & \\
\hline France & MATH & Antoine & Institut de Recherches Economiques et Sociales (IRES), Paris \\
\hline \multirow[t]{2}{*}{ Germany } & BAHLE & Thomas & Mannheimer Zentrum für Europäische Sozialforschung (MZES) \\
\hline & HUBL & Vanessa & Mannheimer Zentrum für Europäische Sozialforschung (MZES) \\
\hline Greece & MATSAGANIS & Manos & Athens University of Economics and Business \\
\hline Hungary & SZIVÓS & Péter & Tárki, Budapest \\
\hline \multirow[t]{3}{*}{ Italy } & KAZEPOV & Yuri & University of Urbino \\
\hline & SABATINELLI & Stefania & University of Milan-Bicocca \\
\hline & ARLOTTI & Marco & University of Brescia \\
\hline Ireland & MAITRE & Bertrand & The Economic and Social Research Institute (ESRI), Dublin \\
\hline \multirow[t]{2}{*}{ Latvia } & VANAGS & Alf & Baltic International Center for Economic Policy Studies (BICEPS), Riga \\
\hline & VASILJEVA & Kristine & Baltic International Center for Economic Policy Studies (BICEPS), Riga \\
\hline \multirow[t]{2}{*}{ Lithuania } & SALANAUSKAITE & Lina & Maastricht University / (CSB), University of Antwerp \\
\hline & LAZUTKA & Romas & Vilnius University \\
\hline Luxembourg & BERGER & Frédéric & $\begin{array}{l}\text { Centre d'Etudes de Populations, de Pauvreté et de Politiques Socio- } \\
\text { Economiques (CEPS), Differdange }\end{array}$ \\
\hline \multirow[t]{2}{*}{ Netherlands } & GOUDSWAARD & Kees & \multirow[t]{2}{*}{ Leiden University } \\
\hline & VAN VLIET & Olaf & \\
\hline \multirow[t]{2}{*}{ Norway } & WEST PEDERSEN & Axel & NOVA, Oslo \\
\hline & KOREN & Charlotte & NOVA, Oslo \\
\hline Poland & PIETKA-KOSINSKA & Katarzyna & Center for Social and Economic Research (CASE), Warsaw \\
\hline \multirow[t]{2}{*}{ Portugal } & BAPTISTA & Isabel & Centro de Estudos para a Intervenção Social (CESIS), Lisboa \\
\hline & BRÁZIA & Ana & Centro de Estudos para a Intervenção Social (CESIS), Lisboa \\
\hline Romania & RAT & Cristina & Sociology Department, "Babes-Bolyai" University Cluj-Napoca \\
\hline Slovakia & GERBERY & Daniel & Institute for Labour and Familiy Research, Bratislava \\
\hline Slovenia & KUMP & Natasa & Institute for Economic Research (IER), Ljubljana \\
\hline \multirow[t]{2}{*}{ Spain } & AIGUABELLA & Joaquim & Gabinet d'Estudis Socials SCCL, Barcelona \\
\hline & LEOTTI & Paolo & \\
\hline Sweden & NELSON & Kenneth & Swedish Institute for Social Research (SOFI), Stockholm \\
\hline UK & BRADSHAW & Jonathan & Social Policy Research Unit (SPRU) / University of York \\
\hline US & STOKER & Robert & Trachtenberg school of public policy and public administration \\
\hline
\end{tabular}


Figure A. Trends in gross social assistance benefits relative to gross average wage, 19922000

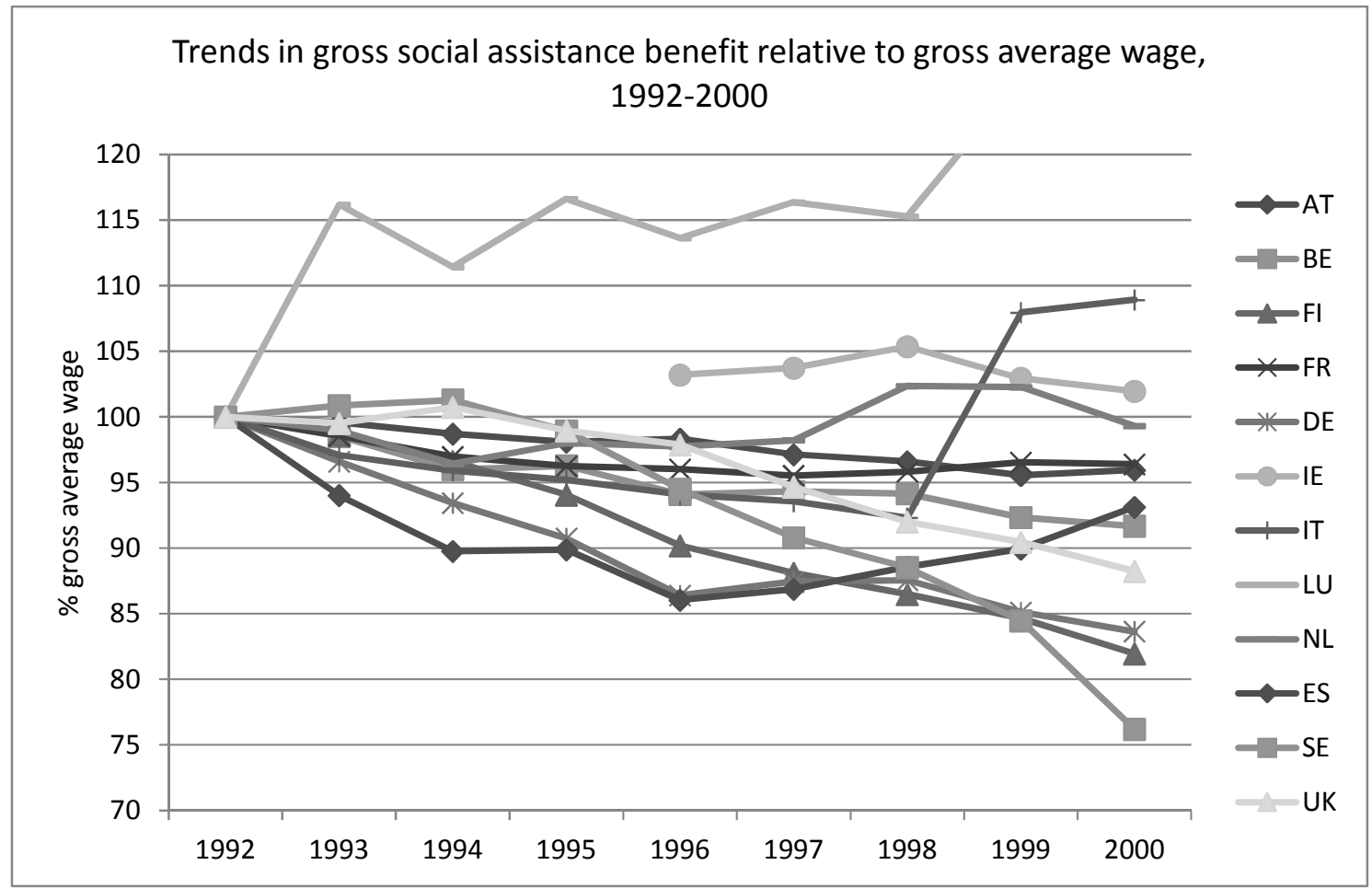

Source: CSB-MIPI (Van Mechelen, et al., 2011) 


\section{References}

Bogdanov, G., \& Zahariev, B. (2009). Analysis of the situation in relation to minimum income schemes in Bulgaria: On behalf of the European Commission DG Employment, Social Affairs and Equal Opportunities.

Bonoli, G. (2010). The Political Economy of Active Labor-Market Policy. Politics and society, 38, 435-457.

Bradshaw, J., \& Finch, N. (2002). A comparison of child benefit packages in 22 countries. Norwich: UK Department for work and pensions.

Bundesagentur für Arbeit. (2010). Arbeitsmarkt 2009. Amtlichen Nachrichten der Bundesagentur für Arbeit, 58(2). Retrieved from http://statistik.arbeitsagentur.de/StatischerContent/Arbeitsmarktberichte/Jahresbericht-Arbeitsmarkt-Deutschland/GenerischePublikationen/Arbeitsmarkt-2009.pdf

Cantillon, B., Van Mechelen, N., Marx, I., \& Van den Bosch, K. (2004). The evolution of minimum income protection in 15 European Countries, 1992-2001 (CSB Berichten). Antwerp: Herman Deleeck Centre for Social Policy.

Castles, F. G. (2010). Black swans and elephants on the move: the impact of emergencies on the welfare state. Journal of European Social Policy, 20, 91.

Centraal Bureau voor de Statistiek. (2011). Statline. Retrieved 27.05.2011: http://statline.cbs.nl/statweb/

Chung, H., \& Thewissen, S. (2011). Falling back on old habits? A comparison of the social and unemployment crisis reactive policy strategies in Germany, the UK and Sweden. Social Policy \& Administration, 45(4), 354-370.

Citizens information board. (2011, 4/1/2011). Back to work allowance. Retrieved 20.5.2011, from http://www.citizensinformation.ie/en/social_welfare/social_welfare_payments/social_welfare _payments_and_work/back_to_work_allow.html

De Deken, J., \& Clasen, J. (2011). Tracking caseloads: the changing composition of working-age benefit receipt in Europe. In J. Clasen \& D. Clegg (Eds.), Regulating the risk of unemployment: national adaptations to post-industrial labour markets in Europe. Oxford: Oxford University Press.

Department for work and pensions. (2011). Department for work and pensions statistical tabulations. Retrieved 27.05.2011: http://83.244.183.180/100pc/

Department of social protection. Statistical information on social welfare services 2009 Available from http://www.welfare.ie/EN/Policy/ResearchSurveysAndStatistics/Documents/2009stats.pdf

Dukelow, F. (2011). Economic Crisis and Welfare Retrenchment:Comparing Irish Policy Responses in the 1970s and 1980s with the Present. Social Policy \& Administration, 45(4), 408-429.

Eardley, T., Bradshaw, J., Ditch, J., Gough, I., \& Whiteford, P. (1996). Social assistance in OECD countries: synthesis report. London.

Eichhorst, W., \& Konle-Seidl, R. (2008). Contingent convergence: a comparative analysis of activation policies. Bonn: IZA.

European Commission. (2010). Joint Report on Social Protection and Social Inclusion 2010.

European Commission. (2011). Mutual Information System on Social Protection (MISSOC). Retrieved August 2011, from European Commission: http://ec.europa.eu/employment_social/missoc/db/public/compareTables.do?year=20110101 \&lang=en

Resolution of 20 October 2010 of the European Parliament on the role of minimum income in combating poverty and promoting an inclusive society in Europe (2010).

Eurostat. (2011). Statistics by theme. Retrieved 8 July 2011: http://epp.eurostat.ec.europa.eu/portal/page/portal/statistics/themes

Fahey, T. (2007). The Case for an EU-wide Measure of Poverty. European Sociological Review, 23(1), 35-47.

Figari, F., Matsaganis, M., \& Sutherland, H. (2011). Are European social safety nets tight enough? Coverage and adequacy of minimum income schemes in 14 EU countries (No. GINI Discussion paper no.2). 
Financial Supervisory Authority, \& Social Insurance Institution. (2010). Statistical Yearbook on Unemployment Protection in Finland 2009 Available from http://www.kela.fi/it/kelasto/kelasto.nsf/alias/TtE_09_pdf/\$File/TTE_09.pdf?OpenElement

Food Research and Action Center. (2011). SNAP/Food Stamp Monthly Participation Data. Retrieved 27.05.2011: http://frac.org/reports-and-resources/snapfood-stamp-monthly-participation-data/

Generalitat de Catalunya. (2010). Renda Mínima d'inserció: renda mínima d'inserció i empreses collaboradores d'inserció. Any 2009. Retrieved 27.05.2011: http://www20.gencat.cat/portal/site/observatoritreball/menuitem.39202212e4b9b7c298740d6 3b0c0e1a0/?vgnextoid=6b41d247538af110VgnVCM1000000b0c1e0aRCRD\&vgnextchannel $=6 \mathrm{~b} 41 \mathrm{~d} 247538 \mathrm{af} 110 \mathrm{VgnVCM} 1000000 \mathrm{~b} 0 \mathrm{c} 1 \mathrm{e} 0 \mathrm{aRCRD} \& \mathrm{vgnextfmt}=$ default

Hemerijck, A. (2012). Changing welfare states. Oxford: Oxford University Press.

Hölsch, K., \& Kraus, M. (2004). Poverty alleviation and the degree of centralization in European schemes of social assistance. Journal of European Social Policy, 14(2), 143-164.

Idescat. (2011). Població total. Grups d'edat. Retrieved November 2011, from Idescat: http://www.idescat.cat/treball/epa?tc=4\&id=xc0102\&dt=2000\&x $=4 \& \mathrm{y}=4$

Immervoll, H. (2009). Minimum-Income Benefits in OECD Countries: Policy Design, Effectiveness and Challenges (IZA Discussion Paper No. 4627): IZA.

Immervoll, H., \& Llena-Nozal, A. (2011). Social Policies for a Recovery (IZA Policy Paper no. 32). Bonn: IZA.

Nelson, K. (2010). Social assistance and minimum income benefits in old and new EU democracies. International Journal of Social Welfare, 19, 367-378.

Nelson, K. (forthcoming). Social assistance and EU poverty thresholds 1990-2008. Are European welfare systems providing just and fair protection against low income? European Sociological Review.

OECD. (2010). Benefits and Wages: Country specific files. Retrieved March 22, 2010, from http://www.oecd.org/document/29/0,3343,en_2649 34637_39618653_1_1_1_1,00.html.

OECD. (2011). Backgroung document. Session 1. Economic crisis and beyond: social policies for the recovery. Paper presented at the OECD Ministerial meeting.

Pfeifer, M., Bahle, T., \& Hubl, V. (2011). The last safety net: a handbook of minimum income protection in Europe. Bristol: Policy Press.

POD Maatschappelijke Integratie. (2011). Leefloon, Overzicht van het aantal begunstigden van het leefloon.

Service Nationale d'Action Sociale. (2011). Documents concernant l'execution de la loi RMG. Retrieved 27.5.2011: http://www.snas.etat.lu/Documentation/

Socialstyrelsen. (2011). Socialstyrelsens statistikdatabas. Retrieved 27.05.2011: http://192.137.163.40/epcfs/index.asp

Statistics Norway. (2011). Statbank Norway. Retrieved 27.05.2011: http://statbank.ssb.no//statistikkbanken/default_fr.asp?PLanguage=1

Statistikos departamentas. (2011). Database of indicators. Retrieved 27.5.2011: http://db1.stat.gov.lt/statbank/default.asp?w=1680

U.S. Census Bureau. (2011). American FactFinder. Retrieved October 2011, from U.S. Census Bureau: http://factfinder.census.gov/servlet/STGeoSearchByListServlet?ds_name=ACS_2009_1YR G00_\&_lang=en\&_ts=338729739107

Van Mechelen, N., \& Marchal, S. (forthcoming). Trends of social assistance benefit levels for the able-bodied. In I. Marx \& K. Nelson (Eds.), The state of minimum income protection in the European Union. Hampshire: Palgrave.

Van Mechelen, N., Marchal, S., Goedemé, T., Marx, I., \& Cantillon, B. (2011). The CSB Minimum Income Protection Indicators dataset (CSB-MIPI) (No. WP No. 11/05). Antwerp: Herman Deleeck Centre for Social Policy.

Van Mechelen, N., Marx, I., Marchal, S., Goedemé, T., \& Cantillon, B. (2010). The Evolution of Social Assistance and Minimum Wages in 25 European Countries, 2001-2009 (pp. 78p.): unpublished.

Vis, B., van Kersbergen, K., \& Hylands, T. (2011). To what extent did the financial crisis intensify the pressure to reform the welfare state? Social Policy \& Administration, 45(4), 338-353. 
Weishaupt, T. (2011). From the Manpower Revolution to the Activation Paradigm: Explaining Institutional Continuity and Change in an Integrating Europe. Amsterdam: Amsterdam University Press.

Weishaupt, T. (forthcoming). A common turn to activation? In I. Marx \& K. Nelson (Eds.), The state of minimum income protection in the European Union. Hampshire: Palgrave 